\title{
Digging into the Pocketbook: Evidence on Economic Voting from Income Registry Data Matched to a Voter Survey
}

\author{
ANDREW J. HEALY Loyola Marymount University \\ MIKAEL PERSSON University of Gothenburg \\ ERIK SNOWBERG University of British Columbia
}

\begin{abstract}
7 o paint a fuller picture of economic voters, we combine personal income records with a representative election survey. We examine three central topics in the economic voting literature: pocketbook versus sociotropic voting, the effects of partisanship on economic evaluations, and voter myopia. First, we show that voters who appear in survey data to be voting based on the national economy are, in fact, voting equally on the basis of their personal financial conditions. Second, there is strong evidence of both partisan bias and economic information in economic evaluations, but personal economic data is required to separate the two. Third, although in experiments and aggregate historical data recent economic conditions appear to drive vote choice, we find no evidence of myopia when we examine actual personal economic data.
\end{abstract}

\section{INTRODUCTION}

$\mathbf{E}$ conomic performance is one of the best predictors of election outcomes (Duch and Stevenson 2008; Lewis-Beck and Paldam 2000). Yet, the mechanisms by which money flowing through people's pockets and communities maps into votes is much less clear (Ansolabehere, Meredith, and Snowberg 2014). Moreover, the economic voting literature is rife with inconsistencies. The survey-based literature concludes that voters are sociotropic-caring more about national than personal (pocketbook) economic conditions, backward-looking, and myopic (Fiorina 1981; Kinder and Kiewiet 1979; Kiewiet and Lewis-Beck 2011). Meanwhile, the macro-based literature-and

Andrew J. Healy is Professor, Department of Economics, Loyola Marymount University (ahealy@lmu.edu).

Mikael Persson is Associate Professor, Department of Political Science, University of Gothenburg (mikael.persson@ pol.gu.se).

Erik Snowberg is Canadian Excellence Research Chair in DataIntensive Methods in Economics at the Vancouver School of Economics, University of British Columbia; Professor of Economics and Political Science, Division of the Humanities and Social Sciences, California Institute of Technology; Research Associate, National Bureau of Economic Research, California Institute of Technology, University of British Columbia (snowberg@caltech.edu).

We gratefully acknowledge the assistance of Statistics Sweden. Snowberg acknowledges the support of NSF grants SES-1156154 and SMA-1329195. Persson acknowledges support from the WennerGren Foundations, the Swedish Research Council for Health, Working Life and Welfare, and the Royal Swedish Academy of Sciences. We thank Steve Ansolabehere, Love Christensen, Bob Erikson, Mikael Gilljam, Rod Kiewiet, Kalle Lindgren, Peter Loewen, Sven Oskarsson, and Chris Wlezien for helpful comments, as well as conference participants at APSA 2014 in Washington, DC, and seminar participants at the Department of Economics, Loyola Marymount University and at the Department of Political Science, University of Gothenburg. The register data used in this article is confidential and cannot be disclosed by the authors. However, interested scholars can apply for access to our dataset through Statistics Sweden. Instructions for doing so, and code to reproduce our results, may be found on Dataverse at http://doi.org/10.7910/DVN/OJQJRM.

Received: October 26, 2016; revised: April 1, 2017; accepted: July 7, 2017. First published online: September 5, 2017. the political economy theory underlying it-assumes votes come from the pocketbook, and largely concludes that voters are, on aggregate, forward looking and highly capable of disciplining politicians for economic outcomes (Erikson, MacKuen, and Stimson 1989, 1992, 2000, 2002).

Some of these inconsistencies are due to imperfect data. Almost all of the evidence about the individuallevel effects of economic circumstances comes from survey questions that depend on recollections. Moreover, these recollections are elicited at only a single point in time: right before or right after an election (Lewis-Beck and Paldam 2000). This is potentially problematic, as partisan preferences, limited human memory, and other factors might color subjective assessments, making such survey data less than ideal (Wlezien, Franklin, and Twiggs 1997). On the other hand, macro data obscures individuals, leaving inferences subject to ecological biases (Kramer 1983). ${ }^{1}$

Using improved data, we seek to paint a full picture of the economic voter and understand the roots of both pocketbook and sociotropic voting. In doing so, we contribute to three long-standing debates in the economic voting literature: pocketbook versus sociotropic voting, the effects of partisanship on economic views, and whether or not voters are myopic. Our data links a nationally-representative election survey to comprehensive personal financial information. This financial data provides respondents' household income-as verified by tax returns-each year for a complete fouryear term of a government. Merging this data with a detailed national election survey allows us to directly analyze the impact that an individual's financial history has on economic evaluations, vote choice, and political preferences. The results suggest greater commonality

\footnotetext{
${ }^{1}$ Interestingly, Kramer argued that survey-based research, because it is cross-sectional, rather than time-series, is more likely to be subject to ecological fallacies. A more general perspective is that using data about polities to make claims about individuals, or individual data to make claims about polities, is subject to ecological biases.
} 
between individual behavior and macro patterns than previously appreciated.

In particular, we demonstrate that pocketbook considerations-that is, personal economic circumstances - are, in our data, at least as important as sociotropic ones. Traditional analyses of the survey data we use support the literature's conclusion that sociotropic motivations have the greatest influence on voters. However, when personal financial data is added to the analysis, those same voters are shown to actually vote equally on the basis of their pocketbooks. We then use our data to understand the sources of bias in economic evaluations. Both pocketbook and sociotropic evaluations include partisan bias. However, that bias is twice as large in sociotropic evaluations, perhaps leading to its prominence in predicting vote choice. Finally, counter to prior research, when focusing on personal financial circumstances, vote choice does not exhibit an end-year bias - an over-weighting of economic information in the final year(s) of a government's term. In particular, we demonstrate that respondents put the most weight on income changes in the first year of the government's term. In our study, this timing coincides with the government's implementation of a large tax cut.

Together, the results show that our understanding of economic voting depends crucially on the quality of available data. Fine-grained personal financial data show the hidden impact of pocketbook considerations, the nature of partisan bias in economic perceptions, and the way that personal economic experiences over time affect vote choice. Together, these data paint a picture of economic voters who seem reasonably well informed of their own economic situation, and use this information rationally. Our discussion, in the final section, gives a more nuanced analysis, and suggests that these findings should provide renewed optimism for proponents of democratic accountability.

\section{BACKGROUND}

Our data covers the 2010 Swedish election and the previous four years of personal income. ${ }^{2}$ While there are theoretical reasons to believe that economic voting in Sweden may not generalize to other places - in particular, Sweden has a small open economy (Duch and Stevenson 2008) - our study encompasses two results that suggest otherwise. First, when examining survey data on economic perceptions, Swedish voters appear sociotropic, just like voters in other countries. Second, Swedes appear, in survey experiments, to suffer from end-year bias-just like voters in the U.S. (Healy and Lenz 2014).

Ahead of the 2006 election, the four center-right parties (the Moderates, the Center Party, the Liberal People's Party, and the Christian Democrats) formed

\footnotetext{
${ }^{2}$ After two years, the personal identifier is stripped from the Swedish National Election Study (SNES) data, due to privacy regulations. Therefore, we could only merge respondents in the 2010 survey with register data. However, approximately half of the respondents in 2010 were also surveyed in 2006.
}

a coalition, the Alliance for Sweden (henceforth, the Alliance). The Alliance's platform consisted of aggressive tax cuts on labor income. These were paid for with cuts to some social services. In addition, the Alliance championed labor-market reforms designed to make employment more flexible. The Alliance won the 2006 election and formed a majority coalition government, ending 12 years of Social Democratic governments.

The campaign of 2006 focused heavily on the domestic economy, and employment was seen as the most important issue among voters (Widfeldt 2007). Soon after the election, the Alliance implemented their centerpiece tax cut, the jobbskatteavdraget, or earned income tax credit (EITC). Like the EITC in the U.S., this primarily benefited low and middle income workers. This tax cut was designed to encourage work, and so only applied to labor income. Rates of taxation on disability benefits, unemployment insurance, pensions, and other social transfers were kept constant.

Median income (in thousands of Swedish KronorSEK), income growth, tax on labor income, and the unemployment rate during the two government terms from 2002 to 2010 are shown in Figure 1. As can be seen, income growth was fairly constant across the period, with the large tax cuts in 2006-2007 leading to a one-year increase in the growth rate. The great recession hit Sweden in 2008, increasing unemployment and lowering the growth rate, although it remained positive.

In 2010, the Alliance successfully defended its economic record, convincing voters that Sweden had handled the external factors causing the great recession better than most other countries in Europe and elsewhere. Although the Alliance increased its vote share, it lost its majority position due to the rising popularity of the anti-immigrant Sweden Democrats (Widfeldt 2011). The Alliance was, however, still the largest block, with 172 seats in parliament, followed by RedGreens - a coalition consisting of the Social Democrats, the Green Party, and the Left Party - which amassed 157 seats.

\section{Economic Voting in Sweden}

As studies of economic voting are conducted in many different countries, and often focus on the U.S., the generalizability of our conclusions relies on whether Swedish voters are different than voters elsewhere. At least for the phenomena we examine, Swedish voters appear remarkably similar to voters elsewhere.

Most recent studies have concluded that Swedish voting behavior, and the importance Swedes place on economic conditions, closely resembles economic voting in other countries (Martinsson 2013). A number of scholarly works based on the Swedish National Election Study (SNES) find that sociotropic considerations dominate pocketbook ones (Jordahl 2006; Holmberg 1984; Holmberg and Gilljam 1987; Gilljam and Holmberg 1993; Holmberg and Oscarsson 2004). Thus, survey evidence from Sweden conforms to the conventional wisdom established in the U.S. and several other countries: the economy matters, and sociotropic evaluations matter substantially more than pocketbook ones 
FIGURE 1. Income, Taxes, and Unemployment in Sweden, 2002-2010
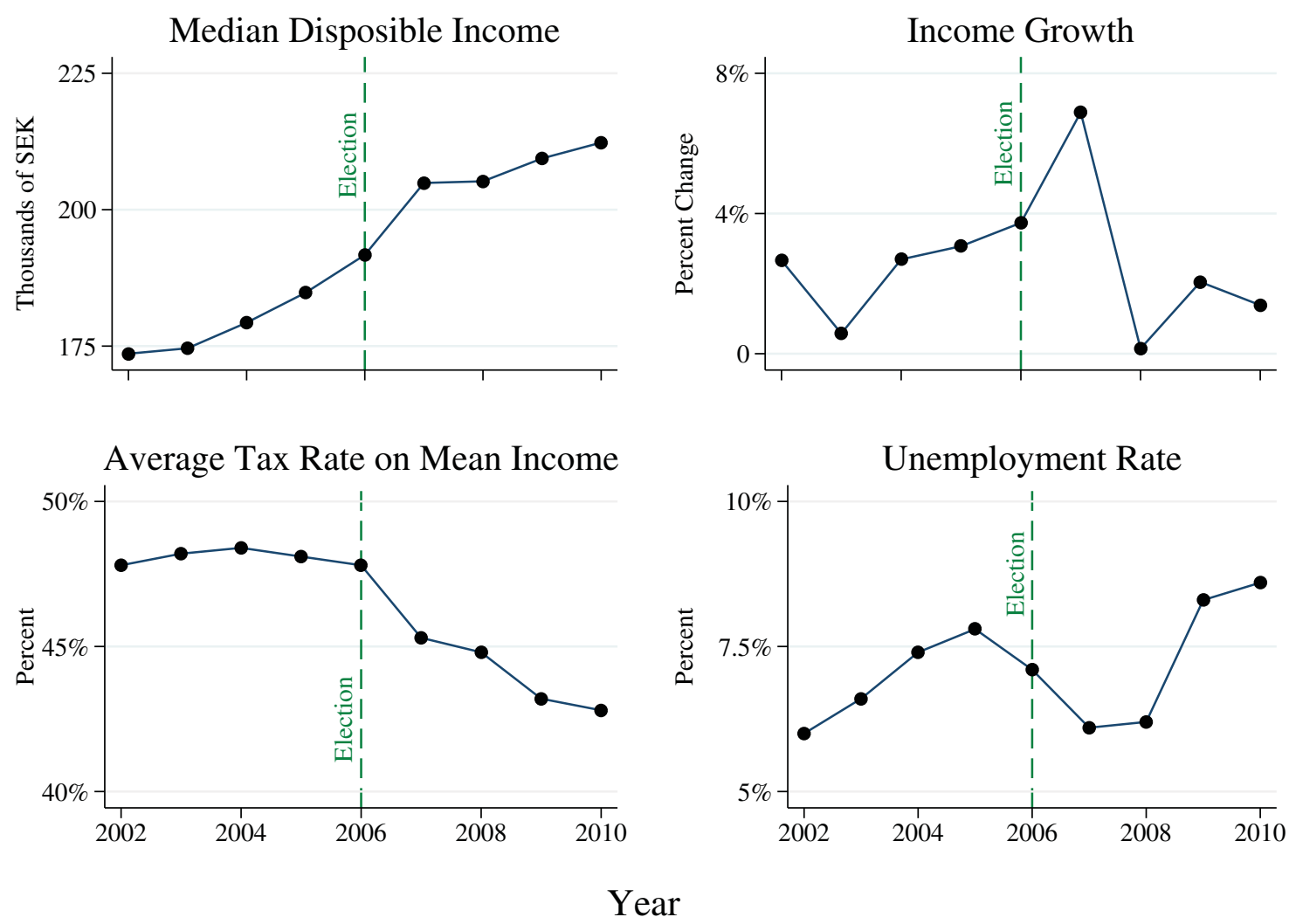

Notes: Data on median disposable income (in constant 2012 prices) is from http://www.statistikdatabasen.scb.se (go to: Hushållens ekonomi / Hushållens ekonomi (HEK) / Inkomstfördelningsundersökningen). Data on taxes is from http://www.ekonomifakta.se (go to: Skatter / Skatt på arbete / Skatt på arbete internationellt). Unemployment is for all people ages 15-74 and is from http://prognos.konj. se/ (go to: Arbetsmarknad /Arbetslöshet och sysselsättningsgrad). All websites accessed August 2014.

(Kinder and Kiewiet 1979). We confirm these previous results from Sweden. Moreover, we replicate the survey-based experiment of Healy and Lenz (2014) and show that the results match those in the U.S.: Swedish voters appear myopic in the data from this experiment. While this cannot prove that the differences between our findings and the previous literature are solely due to superior data, it is consistent with that hypothesis.

Despite these empirical facts, there remain theoretical concerns: in particular, Sweden is a multi-party parliamentary democracy with a small, open economy. On the one hand, the parliamentary system makes it easier for voters to assign credit or blame to the incumbent government for economic circumstances. On the other hand, the multi-party nature of that government, and the size of the economy, make this harder (Duch and Stevenson 2008). Because the electoral coalitions in Sweden were known ahead of the 2010 election, we can mitigate concerns about coalition governments by coding a vote for any member of the incumbent coalition as a vote for the incumbent (1), and a vote for any other party as a vote against (0). There is little to be done about the fact that Sweden's economy is small in global terms. However, it is worth noting that our results show voters rewarding the gov- ernment much more for tax cuts in their first year in office than punishing them for changes in income due to the great recession in the second and third years.

\section{Economic Voting}

The economic voting literature consists of a large number of sub-literatures. Due to the nature of our data, we are able to examine three inter-related topics usually considered in isolation.

A large portion of the economic voting literature attempts to discern whether voters have pocketbook or sociotropic motivations, settling on the latter (Fiorina 1981; Kinder and Kiewiet 1979; Kiewiet and LewisBeck 2011). ${ }^{3}$ A common interpretation of this conclusion is that voters are motivated by public interest (Lewin 1991). Others argue that voters are selfinterested, and the apparent importance of sociotropic evaluations occurs because the national economy is a

\footnotetext{
${ }^{3}$ The part of this literature most closely related to our study compares sociotropic evaluations to actual national and regional conditions (Bisgaard, Dinesen, and Sønderskov 2016; Erikson, MacKuen, and Stimson 1992, 2002; Nadeau, Lewis-Beck, and Bélanger 2013).
} 
clearer signal of governmental performance than personal economic experiences (Ansolabehere, Meredith, and Snowberg 2014; Elinder, Jordahl, and Poutvaara 2015; Kramer 1983; Peltzman 1990). Our findings suggest that it is unlikely voters are primarily motivated by the public interest, and that researchers have been misled by the noisiness of personal economic data. ${ }^{4}$

The pocketbook and sociotropic evaluations that are the basis for studies in the preceding paragraph have received their fair share of criticism. In particular, several studies argue that these evaluations reflect political, rather than economic, considerations. That is, voters decide who they are going to vote for, and then report an economic evaluation that conforms with that choice (Chzhen, Evans, and Pickup 2014; Duch, Palmer, and Anderson 2000; Evans and Andersen 2006; Evans and Pickup 2010, 2013; van der Eijk et al. 2007; Wlezien, Franklin, and Twiggs 1997). Equally, perceptions might be colored by a "partisan lens" that leads voters to view the same economic events more favorably if their preferred party is in office (Zaller 1992). We show that once real economic conditions are taken into account, partisanship still explains some of the voters' economic evaluation. Moreover, partisan bias is a larger component of sociotropic evaluations. Thus, economic evaluations contain both real economic information and partisan bias. However, to tease apart these two contributors to economic evaluations, fine-grained financial data is necessary. ${ }^{5}$

Additionally, many studies argue that voters are poorly informed, and thus subjective evaluations will be noisy (Bartels 1996; Conover, Feldman, and Knight 1986; Hellwig and Marinova 2015; Kramer 1983). Presumably, the level of noise should vary with political sophistication (Alt, Lassen, and Marshall 2016; Duch, Palmer, and Anderson 2000). Surprisingly, there is no agreement in the direction of the relationship. Lowsophistication voters may require media cues to make economic evaluations, and thus, sociotropic evaluations may be more accurate for these voters than pocketbook evaluations (Mutz 1992, 1994). On the other hand, the lack of sophistication may make it difficult for low-sophistication voters to incorporate external information, making pocketbook evaluations more accurate (Delli Carpini and Keeter 1997). We find that increased political sophistication is, on aggregate, unrelated to accuracy of economic evaluations.

\footnotetext{
${ }^{4}$ Consistent with this, studies that examine micro-level data from transfer programs in developing economies find significant pocketbook voting (Manacorda, Miguel, and Vigorito 2011; PopEleches and Pop-Eleches 2012; Richter 2006). These studies are unable to examine sociotropic voting.

${ }^{5}$ A study of particular note is the recent work by Alt and Lassen (2016) that, as with our article, combines survey and registrar data in a Scandinavian country - in their case, Denmark - to examine economic voting. The closest relationship between our article and theirs occurs when we examine the sources of bias and accuracy in pocketbook and sociotropic evaluations. In that section, we focus on the portion of economic evaluations driven by partisanship, while they focus on how providing information changes economic perceptions and reported vote choice. For an analyses of the relationship between wealth and voting in the Swedish context, see Persson and Martinsson (Forthcoming).
}

Concerns have also been raised about voters' abilities to retain and use economic information from early in a government's term. ${ }^{6}$ However, there is some disagreement over whether this reflects rational concerns - as it usually takes some time for economic policy to filter through to economic outcomes (Hibbs 1987; Erikson 1989) - or a myopic bias (Huber, Hill, and Lenz 2012). The latter is of particular concern as it limits democratic accountability, and may lead to inefficient attempts at economic manipulation (Abrams 2006; Achen and Bartels 2004). However, the evidence in all cases comes from surveys or aggregate data. By examining actual personal economic information, we reveal patterns that are incompatible with voter myopia. Namely, in our setting, voters place the most weight on economic information from the beginning of the incumbent government's term, which corresponds to a large tax cut-the government's most important economic policy.

On the whole, then, our data suggest voters are reasonably well informed, at least about their own personal economic circumstances, and seem to use their information rationally. While much of the economic voting literature disagrees with this conclusion, proponents of macropolitics have routinely argued that, on average, voters make very good projections about future economic conditions, and this influences both their partisanship and vote choice (Erikson, MacKuen, and Stimson 1989, 1992, 2000, 2002). ${ }^{7}$ Our findings show individual behavior broadly consistent with this macro perspective.

\section{Data}

Most prior studies of economic voting rely on voters' economic evaluations at a single point in time, or aggregate government statistics on the economy and elections. A number of factors have pushed researchers toward these measurement techniques. First, conventional wisdom holds that quantities are difficult to ask about on surveys, and thus, self-reported income measures have reliability problems (Micklewright and Schnepf 2010; Moore and Welniak 2000; Yan, Curtin, and Jans 2010). Second, recollections of income across time may exceed limited human memory (Withey 1954).

By combining detailed and verified data on income with survey data we can address old debates in new ways. Our survey data comes from the SNES, carried out by Statistics Sweden in collaboration with the University of Gothenburg. The 2010 study was based on a random sample of 3,963 Swedish citizens aged 18 to $80 ; 2,736$ interviews were conducted for a response rate of $69 \%$. Approximately half of the sample was also interviewed for the 2006 SNES; the rest were reinterviewed in 2014. Additionally, half of the sample

\footnotetext{
${ }^{6}$ Wlezien (2015) provides an elegant literature review that shows that U.S. aggregate data is consistent with voters basing their judgements only (and equally) on the final two years of a president's term. ${ }^{7}$ See Green, Palmquist, and Schickler (1998) for a critique of this literature.
} 
was interviewed before the election, and half afterward, with a somewhat different survey instrument. As such, many of our results apply to about one-quarter of the overall sample. ${ }^{8}$ Most interviews were conducted face-to-face in respondents' homes or workplaces. The average time for a full interview was about one hour.

Detailed information about each citizen's income is collected in the Income and Taxation Register. After approval from the Swedish Research Ethical Review Board, Statistics Sweden merged this data with the 2010 SNES. ${ }^{9}$ This data is the exact value in SEK. At the end of 2010 , US $\$ 1 \approx$ SEK6.75.

Our analyses focus on real household disposable income as this is the best summary of economic experience available to us, and a better predictor of election outcomes than other income measures (Achen and Bartels 2004; Bartels 2007; Bartels and Zaller 2001). An individual's personal income will give an inaccurate picture when his or her partner has significantly higher or lower income. Gross income does not factor in taxes and fees, and in many cases, transfers. That is, disposable income is a better measure of the "true parameter of interest" (Kramer 1983)-economic conditions that can be fairly attributed to the government. As other scholars have noted, real disposable income is a "more direct measure of voters' concrete economic pain or pleasure" (Achen and Bartels 2004).

Throughout, we present results from both the full sample and a stable sample. The former contains all respondents. The latter consists of households whose composition remained the same from 2006 to 2010. Household income is affected by the number of adults living in a household. This may change due to divorce, death, a retired parent moving in, or a grown child moving out. As such, our stable sample contains households that went through no such changes from 2006 to 2010. The stable sample also leaves out those that were retired, as they experience very little change in income. ${ }^{10}$ Of the full sample, $60.8 \%$ are in the stable sample, and a further $11.8 \%$ are retired. In general, results in both samples are quite similar.

\section{SOCIOTROPIC AND POCKETBOOK VOTING}

We begin our analysis by re-examining a central finding of the economic voting literature: voters are sociotropic. We find that the portion of pocketbook evaluations that corresponds to real economic conditions

\footnotetext{
${ }^{8}$ Voter turnout was validated with the official registers, and this information is used to correct reported vote choice. Note that turnout in Sweden is quite high: since 1960 it has been greater than $80 \%$.

${ }^{9}$ As mentioned above, half the respondents also took the 2006 SNES, so this data could be matched as well. The time from beginning of the application process to obtaining the data was about 1 year. The data never left Statistics Sweden's servers, which could only be accessed from within Sweden. See Online Appendix A for detailed information on the register data. Because the shadow economy in Sweden is quite small, the data gives a very accurate picture of household income (Guibourg and Segendorf 2007).

${ }^{10}$ The relative stability of retirees' incomes is shown in Online Appendix A. Additionally, taxes on retirement and pension income were kept constant by the Alliance during their first term.
}

is highly correlated with vote choice. This leads naturally into the next two sections, where we first examine the other components of economic evaluations, finding that it is partisan bias, and, in the case of national evaluations, outside information. Then, we examine how vote choice is affected by personal economic conditions across time.

A voluminous literature documents that voters seem to rely more on evaluations of the national economy (sociotropic) rather than personal economic circumstances (pocketbook) in choosing who to vote for (Kiewiet and Lewis-Beck 2011; Kinder and Kiewiet 1979; Lewis-Beck and Paldam 2000). This finding is so ingrained that scholars often forget just how puzzling it is: personal economic experiences are salient and directly experienced, while national economic conditions need to be gleaned from news sources or, possibly, one's surroundings (Grafstein 2009; Kinder and Kiewiet 1981). As Fiorina (1981, 5) notes, pocketbook voting is theoretically more robust, because, "In order to ascertain whether the incumbents have performed poorly or well, citizens need only calculate the changes in their own welfare [emphasis added]."

Here, we document that pocketbook and sociotropic considerations are equally important, once voters' actual economic circumstances are taken into account. To measure sociotropic and pocketbook evaluations, we use the answers to two questions that have been extensively studied in the economic voting literature. Sociotropic evaluations come from answers to:

Would you say that the economic situation in Sweden has improved, stayed the same, or gotten worse, compared with the situation 12 months ago?

whereas the pocketbook evaluation comes from:

If you compare your economic situation with what it was 12 months ago, has it improved, stayed the same, or has it gotten worse?

Both questions allow responses on the same five-point scale, from "much worse", which we code as 1 , to "much better," which we code as 5 .

The role of raw sociotropic and pocketbook evaluations in vote choice are analyzed in Table 1 . In all columns, the dependent variable is whether or not a respondent, whose turnout has been verified, reported a vote for the incumbent Alliance (coded 1), or a vote for a nonincumbent party (coded 0$)$. This is regressed on sociotropic and pocketbook evaluations, and, in some cases, controls, using ordinary least squares (OLS). ${ }^{11}$ The first set of regressions uses the stable sample, and the second set uses all respondents that answered these questions.

The first two columns report the standard analysis of survey data in this literature. They show the standard

\footnotetext{
$\overline{11}$ We avoid discrete choice specifications, such as probit or logit, as these can produce biased and inconsistent coefficients when the dependent variable is measured with error (Hausman 2001). As the dependent variable here comes from a self-report, we cannot be confident that it is exactly measured.
} 


\section{TABLE 1. The Portion of Pocketbook Evaluations Driven by Economic Circumstances Is at Least as Important as Sociotropic Evaluations in Vote Choice}

\begin{tabular}{|c|c|c|c|c|c|c|c|c|}
\hline \multirow{4}{*}{$\begin{array}{l}\text { Evaluation of the } \\
\text { National Economy }\end{array}$} & \multicolumn{4}{|c|}{ Stable Sample } & \multicolumn{4}{|c|}{ Full Sample } \\
\hline & \multicolumn{2}{|c|}{ OLS } & \multicolumn{2}{|c|}{$2 S L S$} & \multicolumn{2}{|c|}{ OLS } & \multicolumn{2}{|c|}{ 2SLS } \\
\hline & $0.18^{\star \star \star}$ & $0.17^{\star \star \star}$ & $0.15^{\star \star \star}$ & $0.14^{\star \star \star}$ & $0.18^{\star \star *}$ & $0.17^{\star \star \star}$ & $0.14^{\star \star \star}$ & $0.11^{* * *}$ \\
\hline & $(.019)$ & $(.020)$ & $(.027)$ & $(0.028)$ & $(.015)$ & $(.016)$ & $(.024)$ & $(.030)$ \\
\hline $\begin{array}{l}\text { Evaluation of Personal } \\
\text { Economic Situation }\end{array}$ & $\begin{array}{l}0.047^{\star *} \\
(.020)\end{array}$ & $\begin{array}{l}0.051^{\star *} \\
(.022)\end{array}$ & $\begin{array}{r}0.22^{\star \star} \\
(.090)\end{array}$ & $\begin{array}{l}0.22^{\star *} \\
(.11)\end{array}$ & $\begin{array}{l}0.034^{* *} \\
(.016)\end{array}$ & $\begin{array}{l}0.043^{\star *} \\
(.017)\end{array}$ & $\begin{array}{l}0.24^{\star \star \star} \\
(.075)\end{array}$ & $\begin{array}{l}0.33^{\star \star \star} \\
(.11)\end{array}$ \\
\hline Constant & $\begin{array}{c}-0.35^{\star \star \star} \\
(.084)\end{array}$ & $\begin{array}{r}-0.43^{*} \\
(.23)\end{array}$ & $\begin{array}{c}-0.79^{* \star \star} \\
(.24)\end{array}$ & $\begin{array}{c}-0.92^{\star *} \\
(.39)\end{array}$ & $\begin{array}{c}-0.27^{\star \star \star} \\
(.068)\end{array}$ & $\begin{array}{c}-0.40^{\star \star} \\
(.15)\end{array}$ & $\begin{array}{c}-0.77^{\star \star \star} \\
(0.19)\end{array}$ & $\begin{array}{c}-1.21^{\star \star \star} \\
(0.37)\end{array}$ \\
\hline Controls & No & Yes & No & Yes & No & Yes & No & Yes \\
\hline Observations & 514 & 513 & 512 & 511 & 858 & 856 & 856 & 854 \\
\hline
\end{tabular}

result: sociotropic evaluations appear to be much more important than pocketbook ones in determining vote choice. The addition of controls has little effect. This matches the extant economic voting literature in both the U.S. and Sweden, emphasizing the general applicability of the results of our further analyses.

To understand the effect of personal economic circumstances on vote choice, and compare it with the effect of sociotropic evaluations, we first project pocketbook evaluations onto actual economic circumstances as observed in the register data. That is, we implement a two-staged-least-squares (2SLS) procedure to isolate the relationship between vote choice and the portion of the pocketbook evaluation correlated with actual economic conditions.

The results of this 2SLS procedure for the stable sample are displayed in the third and fourth column of Table 1. In particular, we regress pocketbook evaluations on economic circumstances - the change in household income in the year preceding the election (2009-2010), and baseline income in 2009. We use the change in the year prior to the election, as this matches the period of time in the evaluative question. ${ }^{12}$ The change is represented with three variables. The $10 \%$ largest positive and negative income shocks are each represented by dummy variables, while all other shocks are entered linearly. This allows us to restrict the influence of outliers, while still preserving the information they contain. ${ }^{13}$

When the projections from this first stage are entered in a second-stage regression, the results are striking. Pocketbook considerations go from being a distant

\footnotetext{
${ }^{12}$ Including changes in preceding years, as in later sections, has little effect.

13 This specification is based on Table 4 of Ansolabehere, Meredith, and Snowberg (2014). The F-statistic on the instruments is usually well above 10 (Angrist and Pischke 2008; Stock, Wright, and Yogo 2012). The first stage, and analyses of robustness to varying the threshold at which an observation is represented by a dummy variable, can be found in Online Appendix B.
}

also-ran to as important as sociotropic ones. ${ }^{14}$ However, the fact that coefficients on sociotropic evaluations decrease only slightly implies that they contain additional information beyond personal economic circumstances. ${ }^{15}$ This is true whether one examines just the stable sample (columns 1-4), or the full sample of respondents (columns 5-8).

The 2SLS estimates provide strong evidence that pocketbook considerations are more important than previously appreciated. Moreover, they call into question a common interpretation of sociotropic voting: that voters are primarily motivated by public interest rather than their own self-interest (Lewin 1991). Statistically, the fact that the 2SLS estimates are so much larger than the OLS estimates is consistent with the presence of substantial white-noise measurement error in pocketbook evaluations. If this were the case, it would attenuate regression coefficients toward zero, and would have prevented previous scholars from appreciating the importance of pocketbook evaluations. ${ }^{16}$

A natural next question arises: what, besides personal economic conditions, drives personal and national evaluations? We turn to this question in the next section.

\footnotetext{
${ }^{14}$ The standard deviations of national and personal economic evaluations are 0.99 and 1.01 in the full sample, and 0.98 and 1.02 in the stable sample.

${ }^{15}$ An obvious caveat is that we cannot project the sociotropic evaluation on national economic conditions, as the national economy was the same everywhere in 2010. Results from similar models, but which include personal and national evaluations separately, are presented in Online Appendix B. These specifications are also consistent with the general conclusion that pocketbook considerations are at least as important as sociotropic considerations. Moreover, the fact that the coefficients on national evaluations do not change much between the OLS and 2SLS specifications (correctly) indicates that national evaluations have a low correlation with personal economic circumstances.

${ }^{16}$ See Gillen, Snowberg, and Yariv (2015) for a treatment of measurement error in surveys and experiments.
} 
FIGURE 2. Those Who Report Improved Economic Circumstances Are More Likely to Vote for the Incumbent.

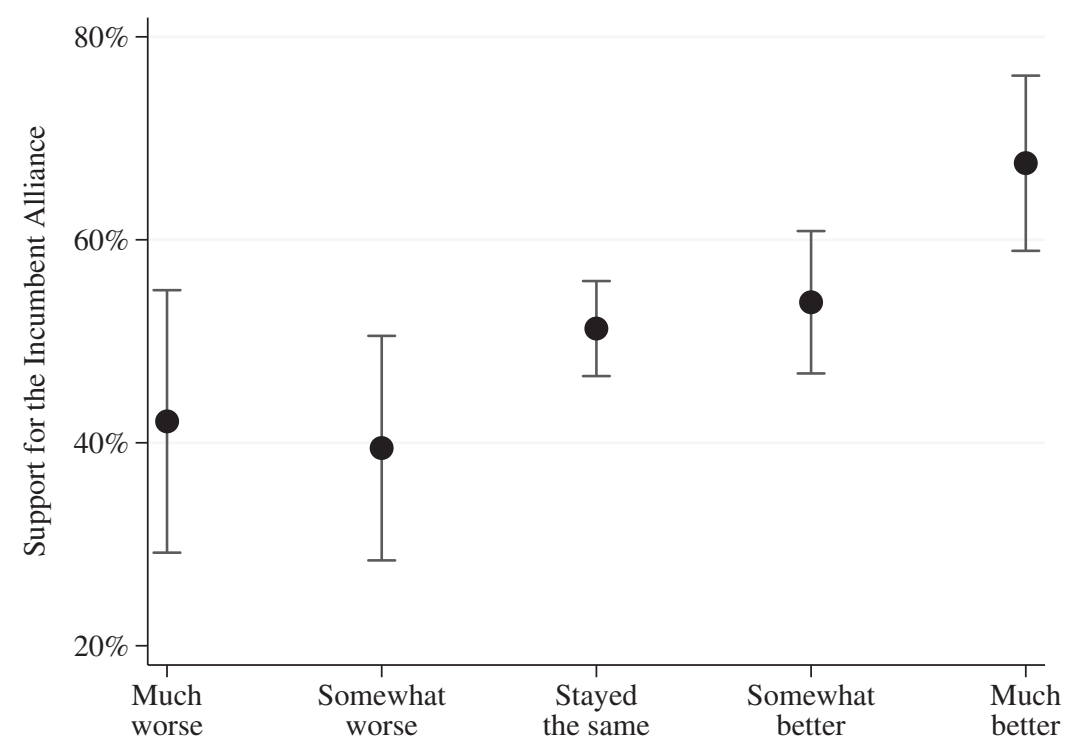

Notes: Figure shows average level of incumbent voting and $95 \%$ confidence intervals for respondents expressing a particular pocketbook evaluation, as indicated on the $\mathrm{x}$-axis.

\section{BIAS AND ACCURACY IN POCKETBOOK EVALUATIONS}

Prior scholarship contends that economic evaluations are driven by partisanship. Figure 2 illustrates this concern: those who report that their personal economic circumstances are "much better" than a year ago are more likely to vote for the incumbent than those who report they are "much worse." But, are they voting for the incumbent because their economic circumstances improved? Or do they report that their economic circumstances improved to align with their partisan vote?

The prior section shows that pocketbook evaluations are not only noise. It establishes that personal economic evaluations reflect actual economic circumstances. We can illustrate this another way: Figure 3 shows that those who reported improved economic circumstances over the previous year experienced greater increases in income than those who reported declining economic circumstances. ${ }^{17}$

Our data provides insights into other determinants of economic evaluations. We first regress personal and national economic evaluations on actual economic circumstances - as in the first-stage specification underlying Table $1-$ and generate residuals. These residuals are the difference between evaluations of two people with the same economic circumstances. Thus, predictors of these residuals are predictors of bias from the

\footnotetext{
17 Although, as income is adjusted for inflation, even those who reported personal economic circumstances were "much worse" had, on average, increasing income.
}

average view. ${ }^{18}$ We regress these residuals on measures of partisanship, political knowledge (measured as the percent of correct answers to 18 general political knowledge questions), and a host of demographic characteristics.

Clear evidence of bias in personal economic evaluations is shown in Table 2. In particular, once actual economic circumstances are taken into account, those who plan to vote for the incumbent Alliance report more favorable economic evaluations.

To reduce concerns that unobserved factors may be driving both the residual and voting for the incumbent in 2010, we examine the relationship between the residuals and vote choice in 2006. In 2006, the Alliance was not incumbent, so if the same unobserved factors were driving both voting in 2006 and residual evaluations in 2010, we would expect to see a negative coefficient on 2006 vote choice. However, this is not what we observe. Instead, the coefficient is positive. It is smaller and insignificant when using the 2006 vote choice-reported concurrently - for the very small sample of people for whom we have this information. The coefficients on 2006 vote choice as recalled in 2010 is very similar to the coefficient on 2010 vote choice. The differences in coefficients on the contemporaneous and recall measures appear to be due to sample size, as an overwhelming majority of respondents ( $92 \%$ ) reported the same 2006 vote choice in both 2006 and 2010.

National evaluations show greater partisan bias and are related to general political knowledge. Coefficients

\footnotetext{
18 Note that this bias might be due to different ways the two individuals interpret a qualitative scale (Ansolabehere, Meredith, and Snowberg 2013).
} 
FIGURE 3. Pocketbook Evaluations Are Correlated with Actual Personal Income Growth.

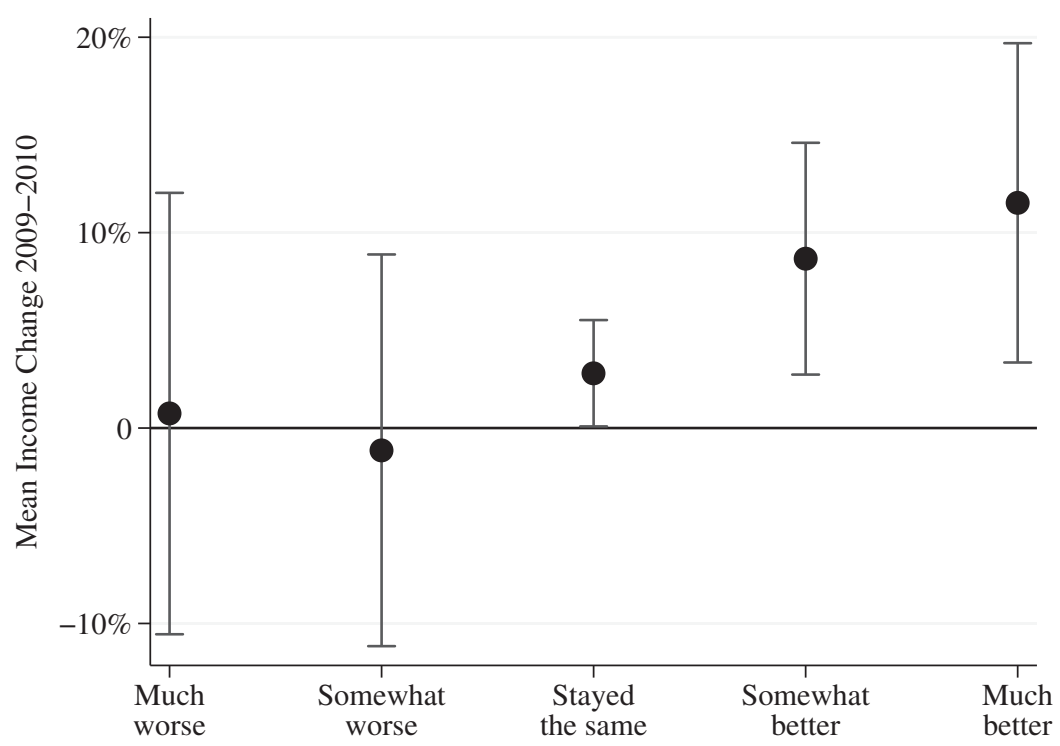

Notes: Figure shows average and 95\% confidence intervals of income change for respondents expressing a particular pocketbook evaluation, as indicated on the x-axis.

\section{TABLE 2. Personal Evaluations Show Evidence of Partisan Bias}

\begin{tabular}{|c|c|c|c|c|c|c|}
\hline \multirow{2}{*}{$\begin{array}{l}\text { Dependent Variable: } \\
\text { Sample: }\end{array}$} & \multicolumn{6}{|c|}{ Residual from Regression of Pocketbook Evaluation on Income Variables } \\
\hline & Stable & Full & Stable & Full & Stable & Full \\
\hline Vote Choice, 2010 & $\begin{array}{l}0.26^{\star \star} \\
(.10)\end{array}$ & $\begin{array}{c}0.20^{\star \star} \\
(.082)\end{array}$ & & & & \\
\hline Vote Choice, 2006 (2006 survey) & & & $\begin{array}{l}0.15 \\
(.16)\end{array}$ & $\begin{array}{c}0.045 \\
(.13)\end{array}$ & & \\
\hline Vote Choice, 2006 (recall, 2010) & & & & & $\begin{array}{r}0.19^{*} \\
(.11)\end{array}$ & $\begin{array}{c}0.25^{\star \star *} \\
(.085)\end{array}$ \\
\hline Political Knowledge & $\begin{array}{l}0.13 \\
(.35)\end{array}$ & $\begin{array}{l}0.24 \\
(.28)\end{array}$ & $\begin{array}{c}-0.73 \\
(.55)\end{array}$ & $\begin{array}{r}-0.14 \\
(.40)\end{array}$ & $\begin{array}{r}-0.27 \\
(.36)\end{array}$ & $\begin{array}{c}-0.073 \\
(.29)\end{array}$ \\
\hline Secondary Education & 0.029 & -0.16 & $\begin{array}{l}-0.35 \\
(27)\end{array}$ & $-0.35^{\star *}$ & 0.044 & $-0.23^{*}$ \\
\hline College Education & $\begin{array}{c}0.25 \\
(.20)\end{array}$ & $\begin{array}{l}0.016 \\
(.14)\end{array}$ & $\begin{array}{r}-0.10 \\
(.28)\end{array}$ & $\begin{array}{r}-0.20 \\
(.18)\end{array}$ & $\begin{array}{l}0.31 \\
(.21)\end{array}$ & $\begin{array}{l}0.005 \\
(.14)\end{array}$ \\
\hline Age/10 & $\begin{array}{r}-0.075 \\
(.27)\end{array}$ & $\begin{array}{r}-0.039 \\
(.16)\end{array}$ & $\begin{array}{c}0.014 \\
(.36)\end{array}$ & $\begin{array}{l}0.31 \\
(.23)\end{array}$ & $\begin{array}{c}-0.11 \\
(.30)\end{array}$ & $\begin{array}{c}0.061 \\
(.18)\end{array}$ \\
\hline $\mathrm{Age}^{2} / 100$ & $\begin{array}{r}-0.006 \\
(.028)\end{array}$ & $\begin{array}{r}-0.011 \\
(.015)\end{array}$ & $\begin{array}{r}-0.006 \\
(.038)\end{array}$ & $\begin{array}{c}-0.044^{\star \star} \\
(.021)\end{array}$ & $\begin{array}{l}0.001 \\
(.031)\end{array}$ & $\begin{array}{r}-0.020 \\
(.016)\end{array}$ \\
\hline Gender & $\begin{array}{l}0.007 \\
(.10)\end{array}$ & $\begin{array}{l}0.11 \\
(.082)\end{array}$ & $\begin{array}{l}0.21 \\
(.16)\end{array}$ & $\begin{array}{l}0.10 \\
(.12)\end{array}$ & $\begin{array}{l}0.069 \\
(.11)\end{array}$ & $\begin{array}{c}0.18^{\star \star} \\
(.085)\end{array}$ \\
\hline Married & $\begin{array}{r}-0.054 \\
(.11)\end{array}$ & $\begin{array}{r}-0.052 \\
(.084)\end{array}$ & $\begin{array}{r}-0.13 \\
(.16)\end{array}$ & $\begin{array}{r}-0.096 \\
(.13)\end{array}$ & $\begin{array}{r}-0.028 \\
(.12)\end{array}$ & $\begin{array}{r}-0.059 \\
(.087)\end{array}$ \\
\hline Immigrant & $\begin{array}{r}-0.15 \\
(.18)\end{array}$ & $\begin{array}{r}-0.088 \\
(.15)\end{array}$ & $\begin{array}{l}0.13 \\
(.25)\end{array}$ & $\begin{array}{c}0.36^{\star} \\
(.20)\end{array}$ & $\begin{array}{r}-0.19 \\
(.18)\end{array}$ & $\begin{array}{r}-0.051 \\
(.15)\end{array}$ \\
\hline Constant & $\begin{array}{l}0.18 \\
(.59)\end{array}$ & $\begin{array}{l}0.27 \\
(.41)\end{array}$ & $\begin{array}{l}0.67 \\
(.85)\end{array}$ & $\begin{array}{c}0.003 \\
(.60)\end{array}$ & $\begin{array}{l}0.46 \\
(.69)\end{array}$ & $\begin{array}{l}0.20 \\
(.45)\end{array}$ \\
\hline Observations & 385 & 627 & 161 & 266 & 321 & 549 \\
\hline
\end{tabular}




\begin{tabular}{|c|c|c|c|c|c|c|}
\hline \multirow{2}{*}{$\begin{array}{l}\text { Dependent Variable: } \\
\text { Sample: }\end{array}$} & \multicolumn{6}{|c|}{ Residual from Regression of National Evaluation on Income Variables } \\
\hline & Stable & Full & Stable & Full & Stable & Full \\
\hline Vote Choice, 2010 & $\begin{array}{c}0.53^{\star \star \star} \\
(.091)\end{array}$ & $\begin{array}{c}0.56^{\star \star \star} \\
(.073)\end{array}$ & & & & \\
\hline Vote Choice, 2006 (2006 survey) & & & $\begin{array}{l}0.31^{\star \star} \\
(.15)\end{array}$ & $\begin{array}{l}0.40^{\star \star \star} \\
(.12)\end{array}$ & & \\
\hline Vote Choice, 2006 (recall, 2010) & & & & & $\begin{array}{c}0.50^{\star * \star} \\
(.099)\end{array}$ & $\begin{array}{c}0.56^{\star * *} \\
(.078)\end{array}$ \\
\hline Political Knowledge & $\begin{array}{l}1.19^{\star \star \star} \\
(.29)\end{array}$ & $\begin{array}{l}1.08^{\star \star \star} \\
(.23)\end{array}$ & $\begin{array}{c}0.42 \\
(.42)\end{array}$ & $\begin{array}{l}0.81^{\star *} \\
(.34)\end{array}$ & $\begin{array}{l}1.00^{* * *} \\
(.32)\end{array}$ & $\begin{array}{l}0.94^{* * *} \\
(.25)\end{array}$ \\
\hline Secondary Education & $\begin{array}{c}0.23 \\
(.16)\end{array}$ & $\begin{array}{l}0.19 \\
(.13)\end{array}$ & $\begin{array}{r}-0.33 \\
(.20)\end{array}$ & $\begin{array}{c}0.19 \\
(.18)\end{array}$ & $\begin{array}{l}0.095 \\
(.19)\end{array}$ & $\begin{array}{c}0.14 \\
(.14)\end{array}$ \\
\hline College Education & $\begin{array}{c}0.31^{\star} \\
(.17)\end{array}$ & $\begin{array}{l}0.26^{\star *} \\
(.13)\end{array}$ & $\begin{array}{r}-0.21 \\
(.22)\end{array}$ & $\begin{array}{c}0.18 \\
(.20)\end{array}$ & $\begin{array}{c}0.18 \\
(.20)\end{array}$ & $\begin{array}{c}0.22 \\
(.14)\end{array}$ \\
\hline Age/10 & $\begin{array}{c}-0.090 \\
(.22)\end{array}$ & $\begin{array}{c}0.038 \\
(.15)\end{array}$ & $\begin{array}{c}-0.74^{* *} \\
(.34)\end{array}$ & $\begin{array}{c}-0.15 \\
(.22)\end{array}$ & $\begin{array}{c}-0.59^{* *} \\
(.25)\end{array}$ & $\begin{array}{r}-0.19 \\
(.16)\end{array}$ \\
\hline $\mathrm{Age}^{2} / 100$ & $\begin{array}{c}0.011 \\
(.024)\end{array}$ & $\begin{array}{r}-0.008 \\
(.014)\end{array}$ & $\begin{array}{l}0.081^{\star *} \\
(.035)\end{array}$ & $\begin{array}{c}0.009 \\
(.022)\end{array}$ & $\begin{array}{c}0.058^{* *} \\
(.026)\end{array}$ & $\begin{array}{c}0.012 \\
(.015)\end{array}$ \\
\hline Gender & $\begin{array}{c}0.017 \\
(.094)\end{array}$ & $\begin{array}{l}0.11 \\
(.076)\end{array}$ & $\begin{array}{l}0.23 \\
(.15)\end{array}$ & $\begin{array}{c}0.25^{\star \star} \\
(.12)\end{array}$ & $\begin{array}{l}0.067 \\
(.11)\end{array}$ & $\begin{array}{c}0.15^{\star} \\
(.081)\end{array}$ \\
\hline Married & $\begin{array}{r}-0.23^{\star \star} \\
(.095)\end{array}$ & $\begin{array}{r}-0.16^{\star \star} \\
(.075)\end{array}$ & $\begin{array}{c}-0.29^{\star \star} \\
(.14)\end{array}$ & $\begin{array}{c}-0.14 \\
(.12)\end{array}$ & $\begin{array}{c}-0.29^{\star \star \star} \\
(.10)\end{array}$ & $\begin{array}{r}-0.21^{\star * *} \\
(.081)\end{array}$ \\
\hline Immigrant & $\begin{array}{c}-0.16 \\
(.17)\end{array}$ & $\begin{array}{c}-0.054 \\
(.14)\end{array}$ & $\begin{array}{r}-0.24 \\
(.46)\end{array}$ & $\begin{array}{c}0.060 \\
(.32)\end{array}$ & $\begin{array}{c}-0.21 \\
(.21)\end{array}$ & $\begin{array}{c}-0.071 \\
(.16)\end{array}$ \\
\hline Constant & $\begin{array}{r}-0.81 \\
(.51)\end{array}$ & $\begin{array}{c}-1.01^{\star \star \star} \\
(.35)\end{array}$ & $\begin{array}{l}1.57^{*} \\
(.80)\end{array}$ & $\begin{array}{r}-0.32 \\
(.56)\end{array}$ & $\begin{array}{l}0.67 \\
(.61)\end{array}$ & $\begin{array}{r}-0.23 \\
(.38)\end{array}$ \\
\hline Observations & 372 & 611 & 159 & 263 & 315 & 541 \\
\hline
\end{tabular}

on partisanship in Table 3 are roughly twice as large as those in Table $2 .{ }^{19}$ Political knowledge is also strongly associated with national evaluations. Those that are more knowledgeable about politics have a much more positive view of the national economic situation. This is independent of education, age, marital status, and, of course, personal economic circumstances. This informed positivity shows that national economic evaluations likely reflect additional information that voters cannot get from their own experiences. ${ }^{20}$

As discussed in the literature review, the relationship between the level of noise in subjective evaluations and political sophistication is unclear. To examine this, we regress the absolute value of the residual from economic evaluations on the same variables as in Table 2. The results, available in Online Appendix C, show little evidence that any of the variables in Tables 2 and 3

\footnotetext{
19 The standard deviation of residuals is 0.98 and 0.97 for personal and national evaluations, respectively. The p-values on the difference between coefficients on partisan indicators across the six columns of Tables 2 and 3 are $0.05,<0.01,0.45,0.05,0.04$, and $<0.01$.

${ }^{20}$ Variables for media usage and political attention were not correlated with either personal or national evaluations. Results available upon request. Note that the effect of a one standard deviation change in partisanship (0.5), as we have measured it, is associated with a slightly larger change in the residual than a one standard deviation change in political knowledge (0.2).
}

are related to the accuracy of economic evaluations. Of particular note, political knowledge is uncorrelated with accuracy of either personal or national evaluations. This is counter to both strains of the prior literature. However, these results should be interpreted carefully, as "accuracy" is defined here as the closeness of a respondent's reported economic evaluations to the average of others with the same economic experiences. Nevertheless, inaccuracies in economic evaluations are not driving the patterns of bias among voters.

Two final notes on these analyses are in order. First, the prior literature uses panel data to provide evidence of partisan bias in economic evaluations. This requires (reasonable) assumptions about the dynamics of partisanship and/or that other economic events (such as a job loss) are correctly reported. Personal financial data allows for the separate identification of economic and political contributions to economic evaluations, and shows they are both important. ${ }^{21}$ Second, there is no variation in macroeconomic conditions we can

\footnotetext{
${ }^{21}$ Still, personal income data does not allow us to quantify changes in wealth due to, say, changes in house prices, changes in job security or employment contracts, or changes in local costs of living. Thus, some economic changes may be unaccounted for in our measure of a person's economic situation, and thus, political factors may be even less important than our results suggest.
} 
exploit to judge the relative quality of economic information contained in personal and national evaluations. However, the macropolitics literature, discussed in the literature review, has shown that voters' forecasts of aggregate economic outcomes are, on average, quite good. Thus, there are other indications that sociotropic evaluations-at least of the prospective varietycontain important economic information as well.

Up until this point we have largely examined election-year income changes, as this is the quantity asked about in retrospective economic evaluations. The literature provides another reason for focusing on this quantity: voters are thought to be myopic, primarily using election-year changes when making voting decisions. Our data allows us to examine this conclusion. We do so in the next section.

\section{IS THE ECONOMIC VOTE MYOPIC?}

Much of the evidence for end-year myopia comes from surveys, survey experiments, and aggregate statistics. Each is potentially problematic. Surveys, administered at only one point in time, consider a single economic setting. Survey experiments assume that voters' reported responses to hypothetical economic conditions are representative of the behavioral consequences of real economic information. Aggregate statistics provide little detail on mechanisms, making it difficult to distinguish a rational focus on the end of a government's term from a myopic bias (Hibbs 1987).

Our data present a unique opportunity to test whether such end-year myopia appears when we examine voters' income across a government's term. To argue that our results generalize, we first verify that Swedish voters respond in the same way as U.S. voters to hypothetical economic conditions in survey experiments. We do so by replicating the experiment of Healy and Lenz (2014) (hereafter, HL) in two Swedish surveys. ${ }^{22}$ We then proceed to examine how vote choice responds to real changes in household income. We find, contrary to the existing survey-based evidenceincluding our own - that Swedish voters put the most weight on personal income changes early in the government's term. While this may seem puzzling, it is actually heartening: as shown in Figure 1, the incumbent government's largest impact on disposable income was felt in the first year of its term, when it sharply cut taxes.

The survey experiment we replicate asks respondents to rate graphs of hypothetical economic growth during a government's term. This is operationalized by showing respondents four bars illustrating the growth rate in each year. ${ }^{23}$ We use the same 25 pictures used in HL, in which each year was independently drawn from a normal distribution parameterized by the first and second moments of postwar yearly growth in the

\footnotetext{
22 Results based on aggregate statistics also suggest that Swedish voters over-weight the last years of a government's terms, as in the U.S. However, interpretation is difficult given the parliamentary structure and unequal term lengths of the Swedish government. Results are available from the authors upon request.

${ }^{23}$ Examples can be found in Online Appendix D.
}

U.S. We supplement this with another 100 hypothetical economic records that are drawn according to a normal distribution parameterized by the first and second moments of yearly growth in postwar Sweden. Thus, some economic records showed steady growth, others showed brief or long-lasting recessions, and some large changes in growth rates.

Our experiment ran on a probability-sampled representative survey of 584 Swedes. As HL largely conducted its experiment on a convenience sampleMechanical Turk -we also ran our experiment on 1,374 Swedes in an opt-in (convenience) sample. ${ }^{24}$ Those in the opt-in sample were shown five hypothetical economic records - two with U.S. growth rates and three with Swedish growth rates, while those in the probability sample were shown seven hypothetical economies - three with U.S. growth rates, and four with Swedish growth rates. Participants were informed that the plots represented growth rates in national average levels of personal income during a government's second term. They were asked to assess, on a fourpoint scale, how good the economy was during the term.

Table 4 analyzes the results of this experiment, following HL. In particular, we regress assessments of each graph on the yearly growth rates therein. To focus on within person variation in these assessments, we include respondent-specific fixed effects. Moreover, we cluster standard errors by hypothetical economy, as this is the unit of treatment.

The results for our Swedish sample replicate those in HL's U.S. sample. Swedish voters heavily over-weight economic growth in the final years of the hypothetical government's term-especially the last year. Indeed, the coefficient on final-year economic growth is significantly larger than the coefficients on any other year. This is true regardless of whether the economic records are meant to mimic the U.S. or Sweden. Moreover, the result is the same whether one examines the opt-in or probability sample.

Having established that Swedes show the same kind of end-year bias in national economic evaluations as U.S. voters in a survey experiment, we turn to register data on personal income. In particular, in Table 5, we regress an indicator for whether the respondent voted for the incumbent center-right Alliance on changes in (logged) household disposable income over the Alliance's term. In all cases, the specifications show that the most important yearly changes in disposable income were in the first years of the Alliance's government. Baseline income-in 2006-also increases the probability that the respondent voted for the Alliance, reflecting the general finding that higher income is associated with right-leaning political views. While the emphasis on income growth in the early years of the Alliance's term is unexpected, it is consistent with the fact that the most important economic changes-ones

\footnotetext{
${ }^{24}$ The survey experiment was conducted in the "Citizen Panel" at the Laboratory of Opinion Research (LORE) hosted by the Multidisciplinary Opinion and Democracy Research Group (MOD) at the University of Gothenburg, Sweden.
} 
TABLE 4. Assessments of Hypothetical Income Growth in Sweden Mirror Results in the U.S.

\begin{tabular}{|c|c|c|c|c|c|}
\hline & Full experiment & U.S. economies & Swedish economies & Opt-in sample & Probability sample \\
\hline Year 1 Growth & $\begin{array}{c}0.10^{\star \star \star} \\
(.022)\end{array}$ & $\begin{array}{l}0.10^{\star *} \\
(.041)\end{array}$ & $\begin{array}{l}0.083^{\star \star \star} \\
(.021)\end{array}$ & $\begin{array}{l}0.12^{\star \star *} \\
(.023)\end{array}$ & $\begin{array}{l}0.068^{\star * *} \\
(.026)\end{array}$ \\
\hline Year 2 Growth & $\begin{array}{l}0.26^{\star \star \star} \\
(.024)\end{array}$ & $\begin{array}{l}0.32^{\star \star \star} \\
(.05)\end{array}$ & $\begin{array}{l}0.24^{\star \star \star} \\
(.022)\end{array}$ & $\begin{array}{l}0.26^{\star \star \star} \\
(.024)\end{array}$ & $\begin{array}{c}0.27^{\star \star \star \star} \\
(.028)\end{array}$ \\
\hline Year 3 Growth & $\begin{array}{l}0.34^{\star \star \star} \\
(.028)\end{array}$ & $\begin{array}{l}0.36^{\star \star *} \\
(.054)\end{array}$ & $\begin{array}{c}0.32^{\star \star \star} \\
(.023)\end{array}$ & $\begin{array}{l}0.34^{\star \star \star} \\
(.028)\end{array}$ & $\begin{array}{l}0.33^{\star \star \star} \\
(.032)\end{array}$ \\
\hline Year 4 Growth & $\begin{array}{l}0.51^{\star * *} \\
(.032)\end{array}$ & $\begin{array}{c}0.50^{\star \star *} \\
(.041)\end{array}$ & $\begin{array}{l}0.55^{\star \star \star} \\
(.033)\end{array}$ & $\begin{array}{c}0.49^{\star \star *} \\
(.032)\end{array}$ & $\begin{array}{l}0.53^{\star \star \star} \\
(.036)\end{array}$ \\
\hline Constant & $\begin{array}{l}2.97^{\star * *} \\
(.17)\end{array}$ & $\begin{array}{l}2.75^{\star \star *} \\
(.25)\end{array}$ & $\begin{array}{l}3.113^{\star \star \star} \\
(.15)\end{array}$ & $\begin{array}{l}3.08^{\star \star \star} \\
(.18)\end{array}$ & $\begin{array}{l}2.79^{\star \star \star} \\
(.18)\end{array}$ \\
\hline Observations & 10,811 & 4,442 & 6,369 & 6,794 & 4,017 \\
\hline $\begin{array}{l}\text { Economies } \\
\text { Individuals }\end{array}$ & 125 & 25 & 100 & 125 & 125 \\
\hline Individuals & 1,958 & 1,953 & 1,953 & 1,374 & 584 \\
\hline
\end{tabular}

\section{TABLE 5. Incumbent Voting Is Most Correlated with Income Changes in the Alliance's First Year in} Office.

\begin{tabular}{|c|c|c|c|c|c|c|}
\hline \multirow{2}{*}{$\begin{array}{l}\text { Sample: } \\
\text { Change in Disposable Household } \\
\text { Income 2006-2007 (log) }\end{array}$} & \multicolumn{3}{|c|}{ Stable } & \multicolumn{3}{|c|}{ Full } \\
\hline & $\begin{array}{l}0.21^{\star \star *} \\
(029)\end{array}$ & $\begin{array}{l}0.20^{\star \star *} \\
(.031)\end{array}$ & $\begin{array}{l}0.13^{\star \star *} \\
(046)\end{array}$ & $\begin{array}{l}0.20^{\star \star \star} \\
(024)\end{array}$ & $\begin{array}{l}0.20^{* \star *} \\
(026)\end{array}$ & $\begin{array}{l}0.093^{\star \star \star} \\
(031)\end{array}$ \\
\hline $\begin{array}{l}\text { Change in Disposable Household } \\
\text { Income 2007-2008 (log) }\end{array}$ & $\begin{array}{l}0.076^{\star \star *} \\
(.025)\end{array}$ & $\begin{array}{l}0.069^{\star * *} \\
(.024)\end{array}$ & $\begin{array}{c}1.070 \\
0.010 \\
(0.036)\end{array}$ & $0.11^{\star \star \star}$ & $0.11^{* \star *}$ & $0.064^{\star *}$ \\
\hline $\begin{array}{l}\text { Change in Disposable Household } \\
\text { Income 2008-2009 (log) }\end{array}$ & $\begin{array}{l}\left(.0202^{\star \star \star}\right. \\
(.024)\end{array}$ & $\begin{array}{l}0.088^{* \star \star} \\
(.024)\end{array}$ & $\begin{array}{c}0.022 \\
(.036)\end{array}$ & $\begin{array}{l}(.0<1) \\
0.10^{\star \star \star} \\
(.020)\end{array}$ & $\begin{array}{l}(.022) \\
0.11^{\star \star \star} \\
(.021)\end{array}$ & $\begin{array}{l}1.054^{*} \\
(.030)\end{array}$ \\
\hline $\begin{array}{l}\text { Change in Disposable Household } \\
\text { Income 2009-2010 (log) }\end{array}$ & $\begin{array}{l}0.051^{* *} \\
(.024)\end{array}$ & $\begin{array}{r}0.044^{*} \\
(.023)\end{array}$ & $\begin{array}{l}0.012 \\
(.013)\end{array}$ & $\begin{array}{l}0.055^{\star \star \star} \\
(.017)\end{array}$ & $\begin{array}{l}0.059^{\star * \star} \\
(.018)\end{array}$ & $\begin{array}{l}0.021 \\
(.015)\end{array}$ \\
\hline $\begin{array}{l}\text { Disposable Household } \\
\text { Income } 2006 \text { (log) } \\
\text { Vote choice } 2006\end{array}$ & $\begin{array}{l}0.17^{\star \star \star} \\
(.020)\end{array}$ & $\begin{array}{l}0.16^{\star \star \star *} \\
(.024)\end{array}$ & $\begin{array}{l}0.076^{\star \star} \\
(.033) \\
0.69^{\star \star \star} \\
(.034)\end{array}$ & $\begin{array}{l}0.18^{\star \star \star} \\
(.016)\end{array}$ & $\begin{array}{l}0.18^{\star * *} \\
(.019)\end{array}$ & $\begin{array}{l}0.088^{\star \star \star} \\
(.025) \\
0.70^{\star \star \star} \\
(.025)\end{array}$ \\
\hline Constant & $\begin{array}{c}-1.68^{\star \star \star} \\
(.26)\end{array}$ & $\begin{array}{c}-1.78^{\star \star \star} \\
(.32)\end{array}$ & $\begin{array}{c}-1.03^{\star \star} \\
(.42)\end{array}$ & $\begin{array}{c}-1.83^{\star \star \star} \\
(.20)\end{array}$ & $\begin{array}{c}-1.82^{\star \star \star} \\
(.24)\end{array}$ & $\begin{array}{c}-0.97^{\star \star \star} \\
(.30)\end{array}$ \\
\hline Controls & No & Yes & Yes & No & Yes & Yes \\
\hline Observations & 1,449 & 1,445 & 546 & 2,384 & 2,376 & 926 \\
\hline
\end{tabular}

that immediately impacted disposable income-were implemented in the Alliance's first year in office, as shown in Figure 1, and discussed in the surrounding text.

The specifications vary according to the sample used-stable or full, whether controls are included, and whether we include vote choice in 2006 as an independent variable. Both varying the sample and the inclusion of controls make very little difference in the results. In all columns, the point estimate on the first year change is larger than the coefficient on changes in income in other years. This is statistically significant (at $p<0.01$ ) for all columns but the sixth. In that column, the difference between the coefficient on the first year change, and the second and third, have p-values of $\approx 0.2$.
As in prior analyses, it is important to understand the effect of outliers on the results. However, unlike in the first-stage specifications underlying Table 1, the coefficients in Table 5 are substantively important. Thus, we check the robustness of these coefficients to omitting those with the largest income shocks. As can be seen in Figure 4-which estimates the specification in Column 5 as more and more outliers are dropped - the coefficients are robust to dropping those with large, and even moderate, income shocks. As expected, the standard errors on these coefficients grow as the sample shrinks, but there is otherwise nothing remarkable in this figure. Most importantly, this analysis shows no sign of end-year bias, and continues to show that income changes in the first year(s) of the Alliance's term had the largest impact on respondents' vote choices. This is 
FIGURE 4. Coefficients in Table 5 Are Robust to Removing Outliers
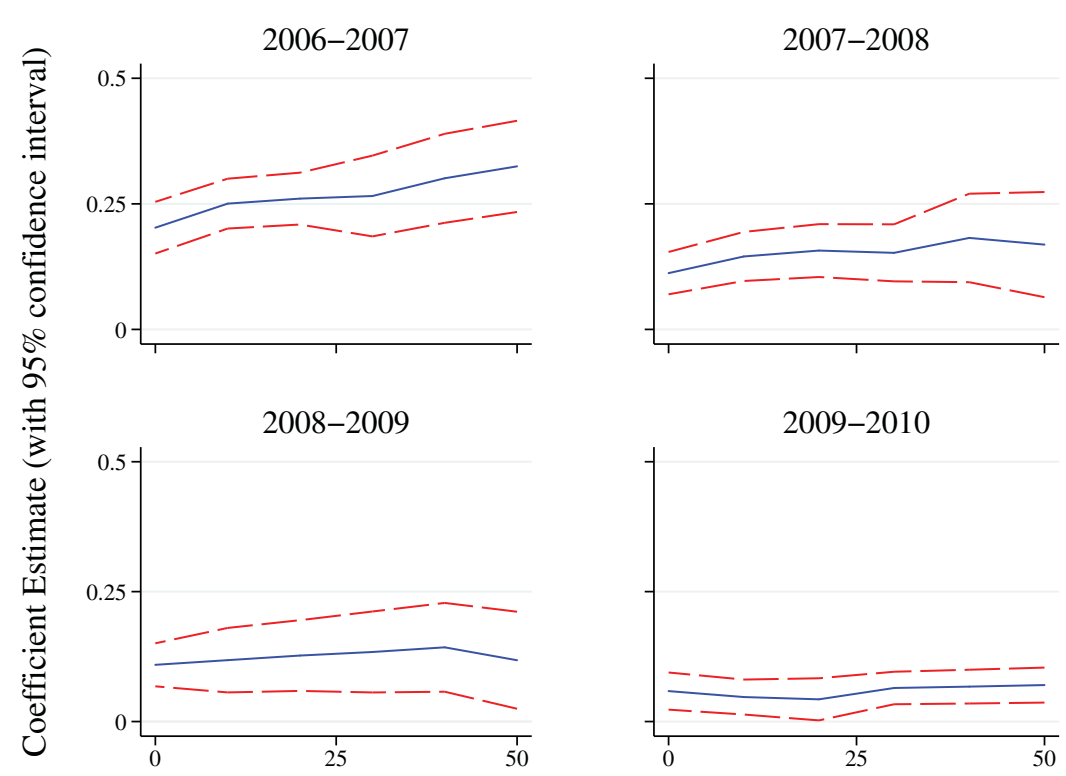

Percentage of Outliers Excluded

true even when we restrict the sample to those who only experienced small to moderate-sized income changes.

The results in Table 5 and Figure 4 are a robust rejection of myopia in pocketbook voting. But what can explain the apparent "hyperopia" in these voters? The simplest explanation is that voters remembered the large tax cuts in the first year of the Alliance's term, and this influenced their vote choice. As shown in Figure 1, and described in the surrounding text, the first-year tax cuts were the most significant economic policy implemented by the Alliance. This is consistent with voters responding to subtle shifts in their own experience when those shifts are accompanied by intense elite messaging (for example, Egan and Mullin 2012).

However, one may be concerned that the tax cuts primarily benefited the Alliance's core supporters who were going to vote for them again anyway. There are three reasons to doubt this interpretation. First, the first-year tax cut was primarily an EITC. As previously mentioned, this tax cut went primarily to low- and middle-income workers. These are not the traditional supporters of the center-right parties that made up the Alliance. Second, in the second and fifth columns, we control for many demographic factors that predict, in Sweden, center-right ideology: in particular, age, gender, education, and marital and migrant status. While these are not perfectly predictive of Alliance support in 2006, the fact that these controls make almost no difference to the results suggests that the bias here must be small. Third, and finally, hyperopia persists, although appears somewhat weaker, when we control for 2006 vote choice explicitly. However, as those who voted for the Alliance in 2006 cannot support it any more than by voting for it again in 2010, this does not reflect any gain in intensity of support by existing Alliance voters. 25

Whichever way one looks at the results in Table 5 and Figure 4, they are inconsistent with a view of voters as suffering from a myopic bias. Moreover, the probable reading of these results is consistent with self-interested voters exercising the levers of democratic accountability. Another piece of evidence points in the same direction. There is a moderate negative correlation $(-0.3)$ between changes in income in the first three years of the Alliance's term. This suggests that those who benefited the most from the Alliance's tax cut were more likely to be among the hardest hit by the recession. This is interesting as it suggests that voters correctly gave the government credit for the increase in disposable income in the first year, but did not incorrectly blame the government for the decrease in disposable income the next year - this decrease was due to an event outside the government's control: the worldwide great recession. Thus, Swedish voters appear to be neither myopic nor hyperopic. They appear to give the government credit where credit is due. In this case, credit happened to be due for the first-year income changes, and not much else.

We conclude in the next section by summarizing our results and discussing how they relate to democratic accountability.

\footnotetext{
${ }^{25}$ In standard models of electoral accountability (Barro 1973; Ferejohn 1986), preference intensity is unimportant as all that determines votes is whether the incumbent is above or below some standard of performance. However, in more complex models with imperfect information, preference intensity may be consequential for accountability.
} 


\section{DISCUSSION}

By augmenting survey data with personal financial data from tax records, we paint a more complete picture of the economic voter than previously possible. In doing so, we revisit three findings from the economic voting literature. Taken together, our analyses show that survey and aggregate data can obscure, and sometimes mislead, researchers about how voters behave.

We find that pocketbook evaluations contain real information about economic experiences, and the evaluations based on those experiences are just as important as national evaluations in determining vote choice. Moreover, the partisan content of national economic evaluations is roughly double that of personal economic evaluations. National evaluations reflect political knowledge while personal evaluations do not. Finally, in our data, voting is largely driven by changes in income during the first year of the government's term. This was when the biggest policy changes occurred. Thus, voters are not myopic when it comes to their personal financial circumstances. In addition, their economic evaluations of the incumbent are plausibly driven by policy.

The fact that pocketbook evaluations may be more important than previously appreciated does not imply that sociotropic evaluations are unimportant. However, we can only speculate about why sociotropic evaluations continue to be important. An explanation consistent with our findings is that the national evaluation reflects additional information about one's own economic circumstances that comes from other sources (Ansolabehere, Meredith, and Snowberg 2014; Kiewiet and Lewis-Beck 2011). Even if voters only care about their own economic circumstances - which seems unlikely - each person only has a single observation of this: their own experience. This is insufficient to make general inferences. The ideal data to have is the economic experience of "people like you." The sample is large enough that one can make inferences, and related enough that these inferences are useful. We speculate that this information - along with the general social concerns of voters - is reflected in the continued importance of national evaluations to vote choice.

This is consistent with both of our findings about national evaluations. As co-partisans are more likely to be "like you" economically (especially in Sweden), partisanship should be a more important factor in national economic evaluations. Moreover, those with greater political information are more likely to have collected economic information about the situation of people "like them." These findings have implications that extend to more general questions of democratic accountability. Findings from the economic voting literature have been used to suggest that voters may be easy to manipulate, and thus have limited ability to control politicians. For example, it has been suggested that end-year myopia can be exploited by incumbents pumping up the economy in the final year of their term to mask otherwise poor economic records (Abrams 2006; Achen and Bartels 2004). Moreover, if voters ignore their own personal economic information, they may be more reliant on the media for information used to evaluate governments (Hetherington 1996), opening themselves to further manipulation. Yet our findings suggest that voters are not myopic and use their own economic information. This warrants a reduction in cynicism about voters' rationality and ability to exercise the levers of democratic accountability.

An easy retort would be that our study considers Swedish citizens, who are different in a number of ways. However, previous scholars, and our own results, suggest that when it comes to economic voting, Swedes look remarkably like U.S. citizens - at least in conventional analyses. Thus, we find it more likely that the discordance between this work and the prior literature are due to better data, rather than vague cultural hypotheses. However, we acknowledge that analyses of finer-grained data in the U.S., or other countries, may produce far different results than what we find here.

We look forward to these analyses. For now, the only thing that is certain is that the increasing availability of personal income data promises to change our understanding of economic voting.

\section{SUPPLEMENTARY MATERIAL}

To view supplementary material for this article, please visit https://doi.org/10.1017/S0003055417000314.

\section{References}

Abrams, Burton A. 2006. "How Richard Nixon Pressured Arthur Burns: Evidence from the Nixon Tapes." Journal of Economic Perspectives 20 (4): 177-88.

Achen, Christopher, and Larry Bartels. 2004. "Musical Chairs: Pocketbook Voting and the Limits of Democratic Accountability." Princeton University, mimeo.

Alt, James E., and David D. Lassen. 2016. "Unemployment Expectations, Information, and Voting: Experimental and Administrative Micro-Evidence." Harvard University, mimeo.

Alt, James E., David D. Lassen, and John Marshall. 2016. "Credible Sources and Sophisticated Voters: When Does New Information Induce Economic Voting?” Journal of Politics 78 (2): 327-43.

Angrist, Joshua D., and Jörn-Steffen Pischke. 2008. Mostly Harmless Econometrics: An Empiricist's Companion. Princeton, NJ: Princeton university press.

Ansolabehere, Stephen, Marc Meredith, and Erik Snowberg. 2013. "Asking About Numbers: Why and How." Political Analysis 21 (1): 48-69.

Ansolabehere, Stephen, Marc Meredith, and Erik Snowberg. 2014. "Mecro-Economic Voting: Local Information and MicroPerceptions of the Macro-Economy." Economics \& Politics 26 (3): 480-510.

Barro, Robert J. 1973. "The Control of Politicians: An Economic Model." Public Choice 14 (1): 19-42.

Bartels, Larry M. 1996. "Uninformed Votes: Information Effects in Presidential Elections." American Journal of Political Science 40 (1): 194-230.

Bartels, Larry M. 2007. Unequal Democracy: The Political Economy of the New Gilded Age. Princeton, New Jersey: Princeton University Press.

Bartels, Larry M., and John Zaller. 2001. "Presidential Vote Models: A Recount." Political Science \& Politics 34 (1): 9-20.

Bisgaard, Martin, Peter Thisted Dinesen, and Kim Mannemar Sønderskov. 2016. "Reconsidering the Neighborhood Effect: Does Exposure to Residential Unemployment Influence Voters' Perceptions of the National Economy?" The Journal of Politics 78 (3): 719-32. 
Chzhen, Kat, Geoffrey Evans, and Mark Pickup. 2014. "When do Economic Perceptions Matter for Party Approval?" Political Behavior 36 (2): 291-313.

Conover, Pamela Johnstone, Stanley Feldman, and Kathleen Knight. 1986. "Judging Inflation and Unemployment: The Origins of Retrospective Evaluations." Journal of Politics 48 (3): 565-88.

Delli Carpini, Michael X., and Scott Keeter. 1997. What Americans Know About Politics and Why it Matters. New Haven, CT: Yale University Press.

Duch, Raymond M., Harvey D. Palmer, and Christopher J. Anderson. 2000. "Heterogeneity in Perceptions of National Economic Conditions." American Journal of Political Science 44 (4): 635-52.

Duch, Raymond M., and Randolph T. Stevenson. 2008. The Economic Vote: How Political and Economic Institutions Condition Election Results. Cambridge: Cambridge University Press.

Egan, Patrick J., and Megan Mullin. 2012. "Turning Personal Experience into Political Attitudes: The Effect of Local Weather on Americans' Perceptions about Global Warming." The Journal of Politics 74 (3): 796-809.

Elinder, Mikael, Henrik Jordahl, and Panu Poutvaara. 2015. "Promises, Policies and Pocketbook Voting." European Economic Review 75: 177-94.

Erikson, Robert S. 1989. "Economic Conditions and the Presidential Vote." The American Political Science Review 83 (2): 567-73.

Erikson, Robert S., Michael B. MacKuen, and James A. Stimson. 1989. "Macropartisanship." American Political Science Review 83 (4): $1125-42$

Erikson, Robert S., Michael B. MacKuen, and James A. Stimson. 1992. "Peasants or Bankers? The American Electorate and the US Economy." American Political Science Review 86 (3): 597-611.

Erikson, Robert S., Michael B. MacKuen, and James A. Stimson. 2000. "Bankers or Peasants Revisited: Economic Expectations and Presidential Approval." Electoral Studies 19 (2): 295-312.

Erikson, Robert S., Michael B. MacKuen, and James A. Stimson. 2002. The Macro Polity. Cambridge, UK: Cambridge University Press.

Evans, Geoffrey, and Robert Andersen. 2006. "The Political Conditioning of Economic Perceptions." Journal of Politics 68 (1) 194-207.

Evans, Geoffrey, and Mark Pickup. 2010. "Reversing the Causal Arrow: The Political Conditioning of Economic Perceptions in the 2000-2004 U.S. Presidential Election Cycle.” Journal of Politics 72 (4): 1236-51.

Evans, Geoffrey, and Mark Pickup. 2013. "Addressing the Endogeneity of Economic Evaluations in Models of Political Choice." Public Opinion Quarterly 77 (3): 735-54.

Ferejohn, John. 1986. "Incumbent Performance and Electoral Control." Public Choice 50 (1): 5-25.

Fiorina, Morris P. 1981. Retrospective Voting in American National Elections. New Haven, CT: Yale University Press.

Gillen, Ben, Erik Snowberg, and Leeat Yariv. 2015. "Experimenting with Measurement Error: Techniques and Applications from the Caltech Cohort Study." California Institute of Technology, mimeo.

Gilljam, Mikael, and Sören Holmberg. 1993. Väljarna inför 90-talet. Stockholm: Norstedts Juridik.

Grafstein, Robert. 2009. "The Puzzle of Weak Pocketbook Voting." Journal of Theoretical Politics 21 (4): 451-82.

Green, Donald, Bradley Palmquist, and Eric Schickler. 1998. "Macropartisanship: A Replication and Critique." American Political Science Review 92 (4): 883-99.

Guibourg, Gabriela, and Bjorn L. Segendorf. 2007. "The Use of Cash and the Size of the Shadow Economy in Sweden." Riksbank Research Paper Series \# 204.

Hausman, Jerry A. 2001. "Mismeasured Variables in Econometric Analysis: Problems from the Right and Problems from the Left." Journal of Economic Perspectives 15 (4): 57-67.

Healy, Andrew, and Gabriel S. Lenz. 2014. "Substituting the End for the Whole: Why Voters Respond Primarily to the Election-Year Economy." American Journal of Political Science 58 (1): 31-47.

Hellwig, Timothy, and Dani M. Marinova. 2015. "More Misinformed than Myopic: Economic Retrospections and the Voter's Time Horizon." Political Behavior 37 (4): 865-87.

Hetherington, Marc J. 1996. "The Media's Role in Forming Voters' National Economic Evaluations in 1992." American Journal of Political Science 40 (2): 372-95.
Hibbs, Douglas. 1987. The American Political Economy: Electoral Policy and Macroeconomics in Contemporary America. Cambridge, MA: Harvard University Press.

Holmberg, Sören. 1984. Väljare i förändring. Malmö: Liber.

Holmberg, Sören, and Mikael Gilljam. 1987. Väljare och val i sverige. Stockholm: Bonnier.

Holmberg, Sören, and Henrik Oscarsson. 2004. Väljare: Svenskt väljarbeteende under 50 år. Stockholm: Norstedts Juridik.

Huber, Gregory A., Seth J. Hill, and Gabriel S. Lenz. 2012. "Sources of Bias in Retrospective Decision Making: Experimental Evidence on Voters' Limitations in Controlling Incumbents." American Political Science Review 106 (4): 720-41.

Jordahl, Henrik. 2006. "An Economic Analysis of Voting in Sweden." Public Choice 127 (3-4): 251-65.

Kiewiet, D. Roderick, and Michael S. Lewis-Beck. 2011. "No Man is an Island: Self-Interest, The Public Interest, and Sociotropic Voting." Critical Review 23 (3): 303-19.

Kinder, Donald R., and D. Roderick Kiewiet. 1979. "Economic Discontent and Political Behavior: The Role of Personal Grievances and Collective Economic Judgments in Congressional Voting." American Journal of Political Science 23 (3): 495 527.

Kinder, Donald R. and D. Roderick Kiewiet. 1981. "Sociotropic Politics: The American Case." British Journal of Political Science 11 (2): 129-61.

Kramer, Gerald H. 1983. "The Ecological Fallacy Revisited: Aggregate-versus Individual-level Findings on Economics and Elections, and Sociotropic Voting." American Political Science Review 77 (1): 92-111.

Lewin, Leif. 1991. Self-Interest and Public Interest in Western Politics. Oxford: Oxford University Press.

Lewis-Beck, Michael S. and Martin Paldam. 2000. "Economic Voting: An Introduction." Electoral Studies 19 (2-3): 11321.

Manacorda, Marco, Edward Miguel, and Andrea Vigorito. 2011. "Government Transfers and Political Support." American Economic Journal: Applied Economics 3 (3): 1-28.

Martinsson, Johan. 2013. "Economic Voting in Sweden 1985-2010." Electoral Studies 32 (3): 470-75.

Micklewright, John, and Sylke V. Schnepf. 2010. "How Reliable are Income Data Collected with a Single Question?" Journal of the Royal Statistical Society: Series A (Statistics in Society) 173 (2): 409-29.

Moore, Jeffrey C., and Edward J. Welniak. 2000. "Income Measurement Error in Surveys: A Review." Journal of Official Statistics 16 (4): 331.

Mutz, Diana C. 1992. "Mass Media and the Depoliticization of Personal Experience." American Journal of Political Science 36 (2): 483-508.

Mutz, Diana C. 1994. "Contextualizing Personal Experience: The Role of Mass Media." The Journal of Politics 56 (3): 689714.

Nadeau, Richard, Michael S. Lewis-Beck, and Éric Bélanger. 2013. "Economics and Elections Revisited." Comparative Political Studies 46 (5): 551-73.

Peltzman, Sam. 1990. "How Efficient is the Voting Market?" The Journal of Law \& Economics 33 (1): 27-63.

Persson, Mikael, and Johan Martinsson. Forthcoming. "Patrimonial Economic Voting and Asset Value: New Evidence from Taxation Register Data.” British Journal of Political Science.

Pop-Eleches, Cristian, and Grigore Pop-Eleches. 2012. "Targeted Government Spending and Political Preferences." Quarterly Journal of Political Science 7 (3): 285-320.

Richter, Kaspar. 2006. "Wage Arrears and Economic Voting in Russia." American Political Science Review 100 (1): 13345.

Stock, James H., Jonathan H. Wright, and Motohiro Yogo. 2012. “A Survey of Weak Instruments and Weak Identification in Generalized Method of Moments." Journal of Business \& Economic Statistics 20 (4): 518-29.

van der Eijk, Cees, Mark Franklin, Froukje Demant, and Wouter van der Brug. 2007. "The Endogenous Economy: 'Real' Economic Conditions, Subjective Economic Evaluations and Government Support." Acta Politica 42 (1): 1-22. 
Widfeldt, Anders. 2007. "The Swedish Parliamentary Election of 2006." Electoral Studies 26 (4): 820-23.

Widfeldt, Anders. 2011. "The Swedish Parliamentary Election of 2010.” Electoral Studies 30 (3): 584-87.

Withey, Stephen B. 1954. "Reliability of Recall of Income." Public Opinion Quarterly 18 (2): 197-204.

Wlezien, Christopher. 2015. "The Myopic Voter? The Economy and US Presidential Elections.” Electoral Studies 39 (3): 195-204.
Wlezien, Christopher, Mark Franklin, and Daniel Twiggs. 1997 "Economic Perceptions and Vote Choice: Disentangling the Endogeneity." Political Behavior 19 (1): 7-17.

Yan, Ting, Richard Curtin, and Matthew Jans. 2010. "Trends in Income Nonresponse over Two Decades.” Journal of Official Statistics 26 (1): 145-64.

Zaller, John. 1992. The Nature and Origins of Mass Opinion. Cambridge, UK: Cambridge University Press. 